\title{
Study on the antimicrobial activity of Ethanol Extract of Propolisagainst enterotoxigenic Methicillin-Resistant Staphylococcus aureus in lab prepared I ce-cream
}

\author{
T A El-Bassiony ${ }^{1}$, Nagah M. Saad ${ }^{1}$, Mona A. El-Zamkan² \\ 1. Department of Food Hygiene, Faculty of Veterinary Medicine, Assiut University, Assiut, Egypt \\ 2. Dept. of Food Hygiene and Control, Faculty of Veterinary Medicine, South Valley University, Qena, Egypt \\ * Corresponding author email: moon_zam@hotmail.com \\ Received: 20-06-2011, Accepted: 28-07-2011, Published Online: 26-12-2011 \\ doi: $10.5455 /$ vetworld.2012.155-159
}

\begin{abstract}
The objective of this study was to investigate the antimicrobial activity of ethanol extract of propolis against enterotoxigenic strain of MRSA which inoculated into lab prepared ice cream. EEP was added to ice cream in 3 concentrations $(150,300$ and $600 \mathrm{mg} / \mathrm{L})$. The prepared ice cream was divided into 2 groups, one stored at freezer temp. at $\left(-5^{\circ} \mathrm{C}\right)$, while the other was kept in deep freezer temp. at $\left(-20^{\circ} \mathrm{C}\right)$. MRSA could not be counted from the $4^{\text {th }}, 2^{\text {nd }}$ and $1^{\text {st }}$ week of storage at freezer temp, while at deep freezer temp. MRSA could not be enumerated from the $3^{\text {rd }}, 1^{\text {st }}$ week and $3^{\text {rd }}$ day of storage in portions contained 150,300 and $600 \mathrm{mg} / \mathrm{LEEP}$, respectively.
\end{abstract}

Keywords: Propolis, MRSA, Ice cream.

To cite this article : El-Bassiony TA, Saad NM, El-Zamkan MA (2012) Study on the antimicrobial activity of Ethanol Extract of Propolis against Enterotoxigenic Methicillin-Resistant Staphylococcus aureus in lab prepared Ice-cream, Vet. World. 5(3): 155-159, doi: 10.5455/vetworld.2012.155-159.

\section{I ntroduction}

In the last few decades staphylococcal food poisoning has been reported as the third cause of foodborne illness in the world (Zhang et al., 1998). Staphylococcus can usually be treated with antibiotics, but some strains of Staphylococci have become resistant to antibiotics that once destroyed it (WebMD, 2010). Recently, the increasing prevalence of MRSA has become a worldwide public health problem. It is the causative pathogen of the majority of nosocomial infections that lead to long hospitalization stays, and high morbidity and mortality rate (Raghukumar et al., 2010). In 1995 the first foodborne outbreak of MRSA was described and caused the death of five out of twenty-one diseased patients (Kluytmans et al., 1995).

In the context of the lack acceptability of synthetic preservatives, there is a growing interest of introducing natural additives to food. Propolis is an interesting alternative to be considered in new applications of food technology as it is extensively used, as phytochemical ingredient, in functional foods at levels that may confer health benefits (International Food Information Service, 2005). Propolis chemical composition is complex and varies according to its botanical and phytogeographical origin, but in general, propolis in nature is composed of $30 \%$ wax, $50 \%$ resin and vegetable balsam, $10 \%$ essential and aromatic oils, $5 \%$ pollens and $5 \%$ various other substances, including organic debris (Greenaway et al., 1991; Bonvehi et al., 1994; Burdock, 1998; Bankova and Marcucci, 2000; Kalogeropoulos et al., 2009 and Petrova et al., 2010).

Bees use propolis as a protective barrier against intruders by sealing holes in their honeycombs (Burdock, 1998; Salatino et al., 2005 and Sforcin, 2007). Moreover, propolis is responsible for the low incidence of bacteria and moulds within the hive as it has antibacterial and antifungal properties. (Bankova et al., 2000). The antimicrobial effect of propolis is due to its components that are mostly of phenolic nature, 
mainly flavonoids, as the simple phenols, phenolic acids and polyphenols are active antimicrobial agents (Cowan, 1999 and Ishida et al., 2011). Propolis has been used as a popular remedy in folk medicine, in apitherapy, as a constituent of biocosmetics, health foods and in numerous other purposes (Bankova et al., 2000 and Banskota et al., 2001).

The antibacterial, antifungal and antioxidant properties of propolis are combined with the fact that several of its constituents present in food and/or food additives, and generally recognized as safe (GRAS) (Burdock, 1998), make it an attractive candidate as a natural preservative in new food applications. This meets the demand for natural antioxidants and antimicrobials, fueled by the increasing consumer awareness for natural, minimally processed foods with traditional preservatives absent or at very low concentrations (Han and Park, 1995 and Tosi et al., 2007). Kilic et al., (2005) and Raghukumar et al., (2010) documented the antimicrobial activity of propolis extract against MRSA, so this study was performed to investigate the effect of ethanol extract of propolis on MRSA inoculated into lab prepared ice cream, as Staphylococci might contaminate ice-cream from non-hygienic serving tools and handlers.

\section{Materials and Methods}

Collection and extraction of propolis: Propolis samples were collected from different regions of Egypt. The obtained crude propolis was stored at $-18^{\circ} \mathrm{C}$ in a domestic freezer till its use. The frozen propolis was grounded using a blender as described by Haddadin et al., (2008). Propolis samples were extracted according to the method described by Biscaia and Ferreira (2009). $5 \mathrm{~g}$ of propolis were placed inside a paper timber and submitted to $6 \mathrm{~h}$ Soxhlet extraction at a maximum temperature of $60^{\circ} \mathrm{C}$, using $150 \mathrm{ml}$ of solvent (ethanol). Waxes from extract were removed by 3 consecutive steps of maintaining at $-18^{\circ} \mathrm{C}$ overnight and filtration at $0^{\circ} \mathrm{C}$. The resulting extracts were evaporated at reduced pressure at a low temperature $\left(<40^{\circ} \mathrm{C}\right)$ in a rotary evaporator to afford a concentrated ethanolic extract of propolis (EEP).
The extract was transferred to small glass vials with a small amount of methanol which evaporated. Different concentrations were prepared $(50,100$, $150,200,400,600,800,1000 \mathrm{mg} / \mathrm{L}$ ) by dissolving the final Ethanol Extract Propolis (EEP) in distillated water to determine the minimum inhibitory concentration (MIC).

Estimation of MI C of EEP: Estimation of MIC was performed according to method (disk diffusion method) prescribed by Silva, et al., 2008.

Preparation of MRSA cellular suspension: Enterotoxigenic MRSA strain was obtained from Food Hygiene Department, Faculty of Veterinary Medicine, Assiut University. The inocula was prepared from MRSA pure culture, incubated in Brain Heart Infusion (BHI) agar for $24 \mathrm{~h}$ at $35^{\circ} \mathrm{C}$. One milliliter of the culture was serially diluted to obtain the count of the organism $/ \mathrm{ml}$. One tenth (0.1) $\mathrm{ml}$ of the obtained cellular suspension $\left(7 \times 10^{8} \mathrm{CFU} / \mathrm{ml}\right)$ was added to $100 \mathrm{ml}$ of brain heart infusion agar, tempered at $45^{\circ} \mathrm{C}$, to obtain a final count of $7 \times 10^{5} \mathrm{CFU} / \mathrm{ml}$, then mixed and poured in Petri dishes and left for $1 \mathrm{~h}$ to solidify.

Detection of MIC: MIC was determined using agar disk diffusion method $(150 \mathrm{mg} / \mathrm{L})$.

Manufacturing of ice cream in lab: Ice cream powder was added to 2 litre of cool sterilized milk then manufactured according to the label of instructions of the produced company. Two $\mathrm{ml}$ of the previously prepared MRSA cellular suspension $\left(7 \times 10^{8} \mathrm{CFU} / \mathrm{ml}\right)$ were added to ice cream and mixed thoroughly, to obtain initial count of $7 \times 10^{5}$ $\mathrm{CFU} / \mathrm{ml}$. Ice cream was divided into 4 portions and 3 concentrations $(150,300 \& 600 \mathrm{mg} / \mathrm{L})$ of EEP were added to 3 portions and the $4^{\text {th }}$ one was kept as a control (EEP free). Each portion was divided into 2 portions, one was kept at freezer $\left(0 \pm 2^{\circ} \mathrm{C}\right)$ and the other was stored at deep freezer $\left(-20^{\circ} \mathrm{C}\right)$. Samples were taken to detect the initial count before addition of EEP and after hardening of ice cream portions at the first 3 days and then weekly for 4 weeks for screening the antimethicillinresistan Staphylococcus aureus (MRSA) activity of EEP. The MRSA count/g was determined using pour plate technique on $\mathrm{BHI}$ agar. 
Study on the antimicrobial activity of EEP against enterotoxigenic MRSA in lab prepared ice cream

Table-1: Effect of different concentrations of ethanol extract propolis (EEP) on enterotoxigenic MethicillinResistant Staphylococcus aureus (MRSA) in lab prepared ice cream stored at freezing temperature $\left(-5^{\circ} \mathrm{C}\right)$.

\begin{tabular}{|c|c|c|c|c|c|c|c|}
\hline \multirow[t]{2}{*}{ Storage period } & \multirow[t]{2}{*}{ Control } & \multirow[b]{2}{*}{$150 \mathrm{mg} / \mathrm{L}$} & \multicolumn{4}{|c|}{ Ethanol Extract of propolis (EEP) } & \multirow[b]{2}{*}{ Red. \%* } \\
\hline & & & Red.\%* & $300 \mathrm{mg} / \mathrm{L}$ & Red.\%* & $600 \mathrm{mg} / \mathrm{L}$ & \\
\hline Initial count & $7 \times 10^{5}$ & $7 \times 10^{5}$ & - & $7 \times 10^{5}$ & - & $7 \times 105$ & - \\
\hline 1st day & $5.9 \times 10^{4}$ & $1.1 \times 10^{4}$ & 81.35 & $4 \times 10^{3}$ & 93.2 & $1 \times 103$ & 98.3 \\
\hline 2nd day & $1.1 \times 10^{5}$ & $9 \times 10^{3}$ & 91.8 & $1 \times 10^{3}$ & 99 & $5.7 \times 102$ & 99.48 \\
\hline 3rd day & $9.5 \times 10^{4}$ & $6.3 \times 10^{3}$ & 93.36 & $8 \times 10^{2}$ & 99.15 & $2 \times 102$ & 99.79 \\
\hline 3rd week & $9 \times 10^{3}$ & 70 & 99.2 & - & - & - & - \\
\hline 4th week & $3.8 \times 10^{3}$ & N.D** & 100 & - & - & - & - \\
\hline
\end{tabular}

* Reduction \%**Not Determined

Table-2: Effect of different concentrations of ethanol extract propolis (EEP) on enterotoxigenic MethicillinResistant Staphylococcus aureus ( MRSA) in lab prepared ice cream stored at deep freezing temperature (-20 ${ }^{\circ} \mathrm{C}$ )

\begin{tabular}{|c|c|c|c|c|c|c|c|}
\hline \multirow[t]{2}{*}{ Storage period } & \multirow[t]{2}{*}{ Control } & \multicolumn{5}{|c|}{ Ethanol Extract of propolis (EEP) } & \multirow[b]{2}{*}{ Red. \%* } \\
\hline & & $150 \mathrm{mg} / \mathrm{L}$ & Red.\%* & $300 \mathrm{mg} / \mathrm{L}$ & Red.\%* & $600 \mathrm{mg} / \mathrm{L}$ & \\
\hline Initial count & $7 \times 10^{5}$ & $7 \times 10^{5}$ & - & $7 \times 10^{5}$ & - & $7 \times 10^{5}$ & - \\
\hline 1st day & $1.1 \times 10^{4}$ & $1.2 \times 10^{3}$ & 89 & $1 \times 10^{3}$ & 90.9 & $1 \times 10^{2}$ & 99 \\
\hline 2nd day & $5 \times 10^{4}$ & $9 \times 10^{2}$ & 98.2 & $5 \times 10^{2}$ & 99 & $1.2 \times 10^{2}$ & 99.76 \\
\hline 3rd day & $1.7 \times 10^{4}$ & $1 \times 10^{2}$ & 99.4 & $1 \times 10^{2}$ & 99.4 & N.D** & 100 \\
\hline 3rd week & $1 \times 10^{3}$ & N.D** & 100 & - & - & - & - \\
\hline 4th week - & - & - & - & - & - & - & \\
\hline
\end{tabular}

* Reduction \%** Not Determined

\section{Results and Discussion}

Results are shown in Table-1 and Table- 2 . Recently, consumers think that the natural food preservatives are better and safer than synthetic ones as they are considered the reason of many carcinogenic and teratogenic attributes as well as residual toxicity. The investigation of natural sources, which offer an unique pool of chemically diverse substances, is a valid approach to the search for new antimicrobials with chemical scaffolds that differ from known antibiotics would have less tendency to generate microbial resistance and health problems. In the last decades, propolis has gained wide acceptance by people from many western and eastern countries. The effect of propolis samples that were collected by Raghukumar et al., (2010) against MRSA was so much higher than that obtained by our propolis extract $(\mathrm{MIC}=64 \mathrm{mg} / \mathrm{L})$, while the antiMRSA effect of 2 of 3 proplis samples groups collected by Kilic et al.,(2005) were closely related to ours (MIC= 161.9 and $101 \mu \mathrm{g} / \mathrm{ml}$ ).

The data presented in Table- 1 showed that, The count of MRSA in control samples was decreased gradually from $\left(2 \times 10^{4} \mathrm{CFU} / \mathrm{g}\right)$ to $\left(3.8 \times 10^{3} \mathrm{CFU} / \mathrm{g}\right)$ at the $4^{\text {th }}$ week. The count of Methicillin-resistant S.aureus, in ice-cream sample portion contained $150 \mathrm{mg} / \mathrm{L}$ ethanol extract of propolis (EEP) and stored at freezing temp. at zero time was $\left(8.7 \times 10^{3} \mathrm{CFU} / \mathrm{g}\right)$ with $(65.5 \%)$ reduction percent then reduced gradually to reach (70 CFU/g) at $3^{\text {rd }}$ week with reduction percent (99.2\%), while through the $4^{\text {th }}$ week MRSA was showed no visible colonies to be enumerated but could be isolated. In the ice cream portion with concentration of $300 \mathrm{mg} / \mathrm{L}$ EEP $M R S A$ count was reduced gradually from $\left(2 \times 10^{3} \mathrm{CFU} / \mathrm{g}\right)$ at Zero time to $\left(1.2 \times 10^{2} \mathrm{CFU} / \mathrm{g}\right)$ with reduction percent of $(99.8 \%)$. At $1^{\text {st }}$ week count of MRSA was diminished gradually from $\left(8.6 \times 10^{2} \mathrm{CFU} / \mathrm{g}\right)$ at 
Zero time to $\left(2 \times 10^{2} \mathrm{CFU} / \mathrm{g}\right)$ at the $3^{\text {rd }}$ day in the portion with $600 \mathrm{mg} / \mathrm{L}$ EEP. On the other hand, MRSA could be isolated till $2^{\text {nd }}$ and $1^{\text {st }}$ week in samples contained 300 and $600 \mathrm{mg} / \mathrm{L}$ EEP, respectively, representing a public health hazard. In relation to control portion MRSA count was reduced to $100 \%$ at $4^{\text {th }}, 2^{\text {nd }}$ and $1^{\text {st }}$ week in ice cream samples with $150 \mathrm{mg}, 300 \mathrm{mg}, 600 \mathrm{mg}$ $\mathrm{EEP} / \mathrm{L}$ and stored at freezing temperature $\left(-5^{\circ} \mathrm{C}\right)$, respectively.

From the data illustrated in Table 2 it is evident that, the antiMARSA effect of propolis in ice cream contained $150 \mathrm{mg} / \mathrm{L}$ EEP and kept at deep freezing temperature reduced the count of MRSA from $\left(3 \times 10^{3} \mathrm{CFU} / \mathrm{g}\right)$ to $(80 \mathrm{CFU} / \mathrm{g})$ during 2 weeks. MRSA count, in ice cream portion with added $300 \mathrm{mg} / \mathrm{L}$ EEP, diminished to $\left(1 \times 10^{2}\right.$ $\mathrm{CFU} / \mathrm{g}$ ) at the $3^{\text {rd }}$ day from $7 \times 10^{2} \mathrm{CFU} / \mathrm{g}$ at 0 time. A very marked reduction in $M R S A$ count occurred at Zero time $\left(2.5 \times 10^{2} \mathrm{CFU} / \mathrm{g}\right)$ which subsequently decreased gradually till became $1.2 \times 10^{2} \mathrm{CFU} / \mathrm{g}$ at the $2^{\text {nd }}$ day. Though $M R S A$ could not be enumerated from $3^{\text {rd }}, 1^{\text {st }}$ week and $3^{\text {rd }}$ day in concentrations of 150,300 and $600 \mathrm{mg} / \mathrm{L}$ EEP at deep freezing temp., yet it assimilated a threat to consumer health as it could be isolated from the samples, respectively. The count of MRSA in control samples was decreased gradually from $8 \times 10^{3}$ to $1 \times 10^{3}$ C.F.U $/ g$ at the $3^{\text {rd }}$ week.

In general we can say that, the anti-MRSA effect of propolis increase by time. The decrease in reduction percent in ice cream samples with $150 \mathrm{mg} / \mathrm{L}$ EEP and kept at deep freezing temperature is not due to the weakness of EEP effect by time, but it is due to the decrease in MRSA count in control samples, which contributed to deep freezing effect, and fixation in the EEP effect in the $1^{\text {st }}$ and $2^{\text {nd }}$ week of storage resulting in diminution of the gap between the $M R S A$ count in control sample and that one with $150 \mathrm{mg} / \mathrm{LEEP}$.

From this study we are not recommending the use of propolis as a food preserver only but also as a treatment for the resistant straininfections such as MRSA. According to our knowledge, so far the represented study is the first one that search on the antimethicilline resistant S.aureus activity of Egyptian propolis.

\section{Acknowledgments}

Authors would like to thank Dr. AbdelSattar M. Abd-Ellah, Professor of Nutrition and Clinical Nutrition, Faculty of Veterinary Medicine, Assiut University, Rasha Ibrahim Mohamed, Assistant lecturer in Department of Nutrition and Clinical Nutrition, Faculty of Veterinary Medicine, Assiut University and Dr. Moustafa Fawzy Aly, Professor of Organic Chemistry, Chemistry Department, Faculty of Science, South valley University for their help in propolis extraction. Also we are thankful to all members of Food Hygiene Department, Faculty of Veterinary Medicine in both Assiut and South Valley Universities.

\section{Conflict of interest}

Authors declare that they have no conflict of interest.

\section{References}

1. Bankova, V. S.; De Castro, S.L. and Marcucci, M.C. (2000): Propolis: recent advances in chemistry and plant origin. Apidologie, 31, 3-15.

2. Bankova, V., and Marcucci, M. C. (2000): Standardization of propolis: present status and perspectives. Bee World, 8(4): 182-188.

3. Banskota, A.H., Tezuka, Y. and Kadota, S. (2001): Recent progress in pharmacological research of propolis. Phytotherapy Research, 15:561-571.

4. Biscaia, D. and Ferreira, S. R. S. (2009): Propolis extracts obtained by low pressure methods and supercritical fluid extraction. J. of Supercritical Fluids, 51: 17-23.

5. Bonvehi, J. S., Coll, F. V., and Jorda, R. E. (1994): The composition, active components and bacteriostatic activity of propolis in dietetics. J. the American Oil Chemist's Society, 71:529-532.

6. Burdock, G. A. (1998): Review of the biological properties and toxicity of bee propolis (propolis). Food and Chemical Toxicology, 36: 347-363.

7. Cowan, M. M. (1999): Plant products as antimicrobial agents. Clinical Microbiological Review, 12(4): 564-582.

8. Greenaway, W., May, J., Scaysbrook, T., \& Whatley, F. R. (1991): Identification by gas chromatography-mass spectrometry of 150 
compounds in propolis. Zeitschrift für Naturforschung, Teil 46C: 111-121.

9. Haddadin, M.S.Y.; Nazer, I.; Abu Raddad, S. J. and Robinson, R.K. (2008): Effect of propolis on two bacteria species with probiotic potential. Pakistan J. Nutrition, 7: 391-394.

10. Han, S. K. and Park, H. K. (1995): A study on the preservation of meat products by natural propolis: effect of EEP on protein change of meat products. Korean J. Animal Sci.: 37: 551-557.

11. International Food Information Service. (2005): IFIS dictionary of food science and technology. Shinfield. FL: International Food Information Service (IFIS Publishing)/Blackwell Publishing. 157.

12. Kalogeropoulos, N.; Konteles, S. J.; Troullidou, E.; Mourtzinos, I. and Karathanos, V. T (2009): Chemical composition, antioxidant activity and antimicrobial properties of propolis extracts from Greece and Cyprus. Food Chemistry: 116, 452-461.

13. Kluytmans, J.; Leeuwen, W. V.; Goessens, W.; Hollis, R.; Hawn Messer, S.; Herwadt, L.; Bruining, H.; Heck, M.; Rost, J.; Leeumen, N. V.; Belkum, A. V. and Verbrugh, H. (1995): Food initiated outbreak of methicillin resistant Staph.aureus analyzed by phenol and genotyping. J. Clin. Microbiol., 33: 1121-1128.

14. Kilic, A.; Baysallar, M.; Besirbellioglu, B.; Salih, B.; Sorkun, K and Tanyuksel, M. (2005): In vitro antimicrobial activity of propolis against methicilline-resistant $S$.aureus and vancomycinresistant Enterococcus faecium. Annals of Microbiol., 55: 113-117.

15. Petrova,A.; Popova, M.; Kuzmanova, C.; Tsvetkova,
I.; Naydenski, H.; Muli, E. and Bankova, V. (2010): New biologically active compounds from Kenyan propolis. Fitoterapia, doi:10.1016/ j.fitote.2010.01.007.

16. Raghukumar, R.; Vali, L.; Watson, D.; Fearnley, J. and Seidel, V. (2010): AntimethicillinResistant S.aureus (MRSA) Activity of 'Pacific Propolis' and Isolated Prenylfl avanones. Phytother. Res. (www.interscience.wiley.com) DOI: $10.1002 /$ ptr.3096.

17. Salatino, A.; Teixeira, E. W.; Negri, G. and Message, D. (2005): Origin and chemical variation of Brazilian propolis. Evidence-based Complementary and Alternative Medicine, 2: 33-38.

18. Sforcin, J. M. (2007): Propolis and the immune system:Areview.J. Ethnopharmacology, 113:1-14.

19. Silva, M. S. S.; De Lima, S. G.; Oliveira, E. H.; Lopes, J. A. D.; Chaves, M. H.; Reis, F. A. M. and L. Citó, A. M. G. (2008): Anacardic acid derivatives from Brazilian propolis and their antibacterial activity. Ecl. Quím., São Paulo, 33, 53-58.

20. Tosi, E. A.; Ré, E.; Ortega, M. E. and Cazzoli, A. F. (2007): Food preservative based on propolis: Bacteriostatic activity of propolis polyphenols and flavonoids upon E.coli. Food Chemistry 104:1025-1029.

21. WebMD (2010): http://www.webmd.com/skinproblems-and-treatments/understanding-mrsamethicillin-resistant-staphylococcus-aureus.

22. Zhang, S.; Iandolo, J. and Stewart, C.(1998): The enterotoxin D plasmid of Staph.aureus encodes a second enterotoxins determinant (sej).FEMS Microbiol. Lett., 168:227-233. 